\title{
Social rights of children with chronic conditions: a critical analysis
} of brazilian public policies

\author{
Direitos sociais das crianças com condições crônicas: análise crítica das políticas públicas brasileiras \\ Derechos sociales de los niños con condiciones crónicas: análisis crítico de las políticas \\ públicas brasileñas
}

Tatiana Silva Tavares ${ }^{1}$ Elysângela Dittz Duarte ${ }^{1}$

Roseni Rosângela de Sena (In memoriam) 1

1. Universidade Federal de Minas Gerais. Belo Horizonte, MG, Brazil.
Corresponding author:

Elysângela Dittz Duarte.

E-mail: elysangeladittz@gmail.com

Submitted on $01 / 17 / 2017$

Accepted on 07/10/2017.

DOI: 10.1590/2177-9465-EAN-2016-0382

\begin{abstract}
Objective: To analyze the current Brazilian public policies that guarantees the social rights of children with chronic conditions, in the areas of health, social assistance and education. Method: Documentary research of laws that shape policies related to the attention to children with chronic illness and people with disabilities in the areas of human rights, health, social assistance and education. A critical analysis of the discourse of three selected legislations was carried out. Results: Children with chronic conditions are covered by legislation for the representation of children with chronic diseases or disabilities. There are discourses of the social model of disability, of children and people with disabilities as subjects of rights, of the state's responsibility in relation to the guarantee of social rights and the co-responsibility of the family. Discourses associated with the ideology of human rights in conflict with the ideology of normalization were evidenced. Conclusion: The actions defined for this group are incipient and with signs of restricting financing, revealing ideological struggles.
\end{abstract}

Keywords: Children with disabilities; Chronic disease; Social Security; Defense of Children and Adolescents; Pediatric Nursing

\section{REsUmo}

Objetivo: Analisar as políticas públicas brasileiras atuais que asseguram os direitos sociais das crianças com condições crônicas, nas áreas da saúde, assistência social e educação. Método: Pesquisa documental de legislações que configuram políticas relacionadas à atenção às crianças com doença crônica e pessoas com deficiência nos âmbitos dos direitos humanos, saúde, assistência social e educação. Foi realizada análise crítica do discurso de três legislações selecionadas. Resultados: As crianças com condições crônicas são contempladas nas legislações pela representação de crianças com doenças crônicas ou com deficiências. Verificam-se discursos do modelo social da deficiência, da criança e da pessoa com deficiência como sujeitos de direitos, da responsabilidade do estado na garantia de direitos sociais e da corresponsabilidade da família. Evidenciaram-se discursos associadas à ideologia de direitos humanos em conflito com a ideologia de normalização. Conclusão: As ações definidas para esse grupo são incipientes e com indícios de restrição de financiamento, revelando lutas ideológicas.

Palavras-chave: Crianças com deficiência; Doença crônica; Seguridade Social; Defesa da Criança e do Adolescente; Enfermagem Pediátrica.

\section{REsumen}

Objetivo: Analizar las políticas públicas brasileñas actuales que aseguran los derechos sociales de los niños con condiciones crónicas, en las áreas de salud, asistencia social y educación. Método: Investigación documental de las legislaciones que configuran políticas relacionadas a la atención de los niños con enfermedad crónica y personas con discapacidad en los ámbitos de los derechos humanos, salud, asistencia social y educación. Se realizó un análisis crítico del discurso de tres legislaciones seleccionadas. Resultados: Las legislaciones contemplan a los niños con condiciones crónicas mediante la representación de niños con enfermedades crónicas o con discapacidades. Se verifican discursos del modelo social de la discapacidad, del niño y de la persona con discapacidad como sujetos de derechos, de la responsabilidad del estado para garantizarles los derechos sociales y de la corresponsabilidad de la familia. Se evidenciaron también discursos asociados a la ideología de derechos humanos en conflicto con la ideología de regulación. Conclusión: Las acciones definidas para ese grupo son todavía incipientes y se notan indicios de financiación limitada, revelando luchas ideológicas.

Palabras clave: Niños con discapacidades; Enfermedad crónica; Seguridad Social; Defensa del Niño y del Adolescente; Enfermería Pediátrica. 


\section{INTRODUCTION}

Social rights were legitimized for Brazilians by the 1988 Federal Constitution, in a context of social movements' demands for democratic reform of the state and reordering of social policies. ${ }^{1}$ According to the Constitution, social rights are "education, health, food, work, housing, transportation, leisure, security, social security, mother and child protection, and assistence to the destitute [...]". ${ }^{2}$ Since the promulgation of this constitution, a legal apparatus was created to regulate social policies. In this study, we emphasize the guarantee of social rights of crianças com condições crônicas (CCC - children with chronic conditions), considering that these conditions have increased worldwide in the last decades due to the progress in health care. ${ }^{3}$ In addition to enabling the survival of these children, it is necessary ethical commitment to their quality of life and social inclusion.

It was adopted the definition of chronic condition in childhood, which includes biological, psychological or cognitive conditions that have lasted or have the potential to last for at least one year and which produce one or more of the following repercussions: limitations of function, activity or social role in comparing children of the same age without changes in terms of growth and development; dependence on compensatory mechanisms - medicines, special food and technological devices - or care due to the limitations of functions; need or use of services above usual for the age, such as health or education services. ${ }^{3}$ This definition also includes children with disabilities.

In 1990, the Estatuto da Criança e do Adolescente (ECA - Child and Adolescent Statute) formalized children and adolescents as subjects of rights, which implied in normative and cultural changes for the public policies and services destined to the care provided to them in the Country. ${ }^{4}$ They were assured, prioritily, the right to life and health, freedom, respect and dignity, family and community coexistence, education, culture, sports and leisure, professionalization and protection at work. ${ }^{5}$ In addition to these rights, the Brazilian Law on the Inclusion of Persons with Disabilities - Estatuto da Pessoa com Deficiência (Disabled Persons Statute) - guaranteed, in 2015, children and adolescents with disabilities the right to equality and nondiscrimination, habilitation and rehabilitation, housing, social care, transport and mobility and accessibility. ${ }^{6}$ These laws are part of a global context for the protection of human rights, with the adoption of Conventions on the Rights of Children in 1989 and of Persons with Disabilities in 2006 in the United Nations General Assembly, and ratified in the country in 1990 and 2009 respectively. ${ }^{7,8}$

However, current studies verified family difficulties in home care, access to and use of health services, education and social assistance, medication, special nutrition and assistive technologies. ${ }^{9-12}$ These difficulties can prevent the fulfillment of the needs of the CCC, compromising their possibilities in terms of autonomy and social participation. In addition to social rights constitutionalised in procedural and legal norms, it is necessary to have institutionalized rights, through a state institutional apparatus, which includes knowledge and practices to implement public policies, allowing the consolidation of citizenship and social inclusion. ${ }^{1}$ Otherwise, the public responsibility for social protection, assumed in the Federal Constitution, ${ }^{2}$ ends up being transferred to the private dimension of the CCC families.

Social rights, constitutive of citizenship, are designed to ensure the equal participation of all members of a community in their basic standards of living. However, in doing so by means of general and abstract rights and duties, they reduce individuality to what is universal in it. The equality of citizenship conflicts with the difference of subjectivity, being that it is selective and leaves untouched differences within the framework of liberal regulation. This tension can only be overcome if the relation between subjectivity and citizenship occurs within the framework of emancipation, in which it is possible to consider citizenship based on forms and criteria of participation, establishing a more balanced relationship with subjectivity. ${ }^{13}$ The institutionalization of rights in the framework of emancipation could favor the recognition of the different needs of CCC.

It is assumed that the formulation and implementation of public policies that ensure the social rights of CCC, recognizing their differences, contribute to their inclusion in society as citizens. In the light of these reflections, the question is: How are CCC represented in legislation? What are the policies and strategies of the Brazilian State to ensure the social rights of these children? The objective of this study is to analyze the current Brazilian public policies that assure the social rights of CCC in the areas of health, social assistance and education.

\section{METHOD}

Documentary research has been carried out on legislation that establishes Brazilian public policies related to children with chronic diseases and people with disabilities in the areas of human rights, health, social assistance and education. Legislation was considered as of 1988, with the Federal Constitution of this year as a framework. The search and retrieval of the documents was carried out between January and December of the year 2015 , from databases of legislation made available by the federal government on the Internet, on the websites of the Ministry of Health (Child Health and Breastfeeding and Health of the Person with desability), of the Ministry of Social Development and Fight against Hunger (Social Welfare), Ministry of Education (Department of Continuing Education, Literacy, Diversity and Inclusion) and the Human rights Secretariat of the Presidency (Children and Adolescents and Persons with disabilities).

A list of 373 laws and regulations retrieved from the Portal of Legislation database was obtained. After reading the preliminary part of the text, which indicates the type of legislation, date of enactment, object and scope, 95 laws and regulations (22 laws, 31 decrees, 5 resolutions and 37 ordinances) related to the object of Study, which were organized in a timeline, were selected. The criterion for selecting the laws and regulations 
to be analyzed in full, in this study, was that the norms would regulate the public policies and strategies in force in the areas of health, social assistance and education for children with chronic diseases and people with disabilities. Considering the relevance and timeliness, three documents were analyzed: Administrative Rule MS/GM No. 1,130, of August 5, 2015; ${ }^{14}$ Law No. 12,435, of July 6, 2011; ${ }^{15}$ And Decree No. 7,611, dated November 17, $2011 .{ }^{16} \mathrm{~A}$ search was made for norms quoted in the documents, and sections of these regulations were analyzed when relevant to answer the study questions.

The target population, objectives, actions and resources and competences established in these laws were described, taking into account the social rights of the CCC. A critical analysis of the discourse guided by the proposal of Fairclough that proposes a three-dimensional framework of analysis was carried out. For the textual analysis the vocabulary was explored. In the analysis of discursive practice, intertextuality was used in the production of the text, by recurrence to other texts (manifest intertextuality) or by elements of the orders of discourse (interdiscursivity). The orders of discourse correspond to the totality of the discursive practices of a social domain and the relations established between them. For the analysis of social practice the ideological and political effects of speech were considered, highlighting the effects of reproduction or transformation. The Representational Meaning related to the discourses was considered, to analyze how CCC are represented. ${ }^{17}$

\section{RESULTS AND DISCUSSION}

Law No. 12,435 of 2011, Decree No. 7,611 of 2011 and Decree MS/GM No. 1,130 of 2015 establish standards for the implementation of Brazilian public policies in the areas of social assistance, education and health related to the social rights of CCC. These laws were drafted by the Civil House of the Presidency of the Republic and by working groups of the respective Ministries. ${ }^{14-16}$

The legislations analyzed were promulgated between 2011 and 2015, in governments that presented as a struggle flag the development of a state of social welfare in the Country. However, during these governments the economic growth of Brazilian capitalism was sought, without breaking with the current neoliberal economic model. The increase in the minimum wage, the creation of a housing program and investment in policies of income transfer was promoted, causing reduction of extreme poverty. ${ }^{18}$

At the time of drafting these laws, the country's indicators revealed a population of children aged 0 to 14 years, corresponding to $24.07 \%$ of the Brazilian population. The infant mortality rate and the mortality rate up to 5 years were, respectively, 16.70 and 18.83 per thousand live-born children. In the age group from 0 to 14 years, $7.53 \%$ had at least one of the deficiencies investigated. ${ }^{19}$ The prevalence of chronic diseases in the age group 0-9 years was $19.3 \%$, which was underestimated, since the sample consisted mainly of individuals aged 18 years or more and chronic diseases that predominantly affect adults. ${ }^{20}$ The percentage of children between 0 and 5 years of age outside the school was $56.85 \%$ and that of extremely poor children aged 0 to 14 was $11.47 \% .{ }^{19}$

In the context of childhood in the country, which required the State to improve the living conditions of the population and access to health and education, the legislation reviewed in this study was promulgated, highlighting the recognition of a social problem and the proposal of solutions. The Política Nacional de Atenção Integral à Saúde da Criança (PNAISC - National Policy on Integral Attention to the Health of the Child), within the scope of the Sistema Único de Saúde (SUS - Unified Health System), prepared by the Ministry of Health, was instituted by Administrative Rule MS/GM No. 1,130, dated August 5, 2015. ${ }^{14}$ Law No. 12,435, of July 6, 2011, instituted by the Civil House of the Presidency of the Republic, ${ }^{15}$ amends Law No. 8,742 of $1993,{ }^{21}$ the Organic Law of Social Assistance, which provides for its organization. Decree No. 7,611, of November 17, 2011, established by the Civil House of the Presidency of the Republic, provides for special education and the Specialized Educational Assistance (ESA) strategy in regular education. ${ }^{16}$ Table 1 presents the target population, objective, actions related to CCC, structure, competences and social participation explained in the laws.

From the approach of the target population it is possible to identify that the representation of children, in relation to those with chronic conditions, presents particularities in the vocabulary and discourses adopted in each law. In the strategic areas of the PNAISC, actions are proposed for "children with chronic diseases" and "children with disabilities", who are considered part of the group of "vulnerable children", for whom it is a challenge to guarantee access to actions and health services. ${ }^{14} \mathrm{~A}$ specification in the representation of children and their needs is evidenced, with recognition of the differences between the various groups when considering previous documents.

In the Social Assistance Law, there are actions aimed at children "in situations of personal and social risk" and "persons with disabilities". Regarding the representation of the disabled person in the current law, the term "portadora" (carrier), adopted in the previous law, was replaced by the preposition "com" (with). Therefore, the definition has been revised by changing the idea of a person who is "incapacitated for independent living and working" by a person who has "long-term physical, mental, intellectual or sensory impairments, which, in interaction with various barriers, may obstruct their full and effective participation in society on an equal basis with other persons". ${ }^{15}$ In the special education decree, students with "disabilities" and "global developmental disorders" were included in the target public, and the "deaf or hearing impairment" and "blind or with low vision"16 were also indicated.

Children are classified into groups in the legislation analyzed, as those with chronic conditions mainly contemplated by children with chronic diseases or disabilities representation. The text of the regulations aims to respond to the needs of different groups of children, expanding the problems to be addressed by social 
Table 1. Description of health legislation, social assistance and education

\begin{tabular}{|c|c|c|c|}
\hline Legislation & $\begin{array}{l}\text { Ordinance MS/GM } \\
\text { No. } 1,130 / 2015\end{array}$ & Law No. $12,435 / 2011$ & Decree No. 7,611/2011 \\
\hline Target population & $\begin{array}{l}\text { From gestation to } 9 \text { years of age, } \\
\text { with special attention to early } \\
\text { childhood and the most vulnerable } \\
\text { populations. }\end{array}$ & $\begin{array}{l}\text { Family, women in the context } \\
\text { of motherhood, child and ado- } \\
\text { lescent, elderly and people with } \\
\text { disabilities. }\end{array}$ & $\begin{array}{l}\text { People with disabilities, with } \\
\text { global developmental disorders } \\
\text { and with high skills or giftedness. }\end{array}$ \\
\hline Objective & $\begin{array}{l}\text { Política Nacional de Atenção } \\
\text { Integral à Saúde da Criança } \\
\text { (PNAISC - National Policy for } \\
\text { Comprehensive Child Health Care): } \\
\text { Promote and protect the health } \\
\text { of the child and breastfeeding } \\
\text { through integral and integrated } \\
\text { care and attention, aiming at } \\
\text { reducing morbidity and mortality } \\
\text { and a facilitating environment for } \\
\text { life with dignified conditions and } \\
\text { full development }\end{array}$ & $\begin{array}{l}\text { Social assistance: social protection } \\
\text { (guaranteeing life, reducing } \\
\text { harm and preventing the } \\
\text { incidence of risks); socio-welfare } \\
\text { surveillance (territorial analysis } \\
\text { of the protective capacity of } \\
\text { families and in it the occurrence } \\
\text { of vulnerabilities, threats, } \\
\text { victimization and damages); and } \\
\text { rights advocacy (ensuring full } \\
\text { access to rights in all socio-welfare } \\
\text { provisions). }\end{array}$ & $\begin{array}{l}\text { Specialized Educational Assistance } \\
\text { (AEE): to provide conditions } \\
\text { for access, participation and } \\
\text { learning in regular education } \\
\text { and to guarantee specialized } \\
\text { support services according to the } \\
\text { individual needs of the students; } \\
\text { ensure the mainstreaming of } \\
\text { special education actions in } \\
\text { regular education; foster the } \\
\text { development of didactic and } \\
\text { pedagogical resources that } \\
\text { eliminate barriers in the teaching } \\
\text { and learning process; and ensure } \\
\text { conditions for further study. }\end{array}$ \\
\hline Actions & $\begin{array}{l}\text { Atenção Integrada às Doenças } \\
\text { Prevalentes na Infância (IMCI } \\
\text { Integrated Attention to Prevalent } \\
\text { Diseases in Childhood), } \\
\text { construction of care guidelines } \\
\text { and lines of care, promotion of } \\
\text { care and home care for children } \\
\text { with chronic diseases; articulation } \\
\text { and intensification of actions for } \\
\text { the inclusion of children with } \\
\text { disabilities in thematic networks, } \\
\text { through the identification of } \\
\text { vulnerability and risk of illness } \\
\text { and disease, recognizing the } \\
\text { specificities of this public. }\end{array}$ & $\begin{array}{l}\text { Benefício de Prestação Continuada } \\
\text { (BPC - Continuous Support } \\
\text { Benefit); Programs aimed at } \\
\text { the integration of people with } \\
\text { disabilities. }\end{array}$ & $\begin{array}{l}\text { Improvement of the specialized } \\
\text { educational service already } \\
\text { offered; Deployment of } \\
\text { multifunctional resource rooms; } \\
\text { continuing teacher education; } \\
\text { training of managers, educators } \\
\text { and other school professionals for } \\
\text { education in the perspective of } \\
\text { inclusive education; architectural } \\
\text { suitability of school buildings } \\
\text { for accessibility; elaboration, } \\
\text { production and distribution } \\
\text { of educational resources for } \\
\text { accessibility. }\end{array}$ \\
\hline Structure & $\begin{array}{l}\text { Neonatal and infant maternal } \\
\text { health network, basic health care, } \\
\text { specialized care. }\end{array}$ & $\begin{array}{l}\text { Reference Center for Social } \\
\text { Assistance and Specialized } \\
\text { Reference Center for Social } \\
\text { Assistance. }\end{array}$ & $\begin{array}{l}\text { Regular schools of the public } \\
\text { network and special or } \\
\text { specialized schools of community, } \\
\text { denominational or philanthropic } \\
\text { institutions. }\end{array}$ \\
\hline Competences & $\begin{array}{l}\text { Partnership between Ministry } \\
\text { of Health (articulating and } \\
\text { supporting), Health Secretariats } \\
\text { of the States (coordinating } \\
\text { implementation) and } \\
\text { Municipalities (implementing). } \\
\text { Tripartite funding. }\end{array}$ & $\begin{array}{l}\text { Articulation between federal } \\
\text { spheres (coordination and general } \\
\text { norms), state and municipal } \\
\text { (coordination and execution). Co- } \\
\text { financing of federated entities, the } \\
\text { Union is responsible for the BPC. }\end{array}$ & $\begin{array}{l}\text { The Ministry of Education } \\
\text { will provide technical and } \\
\text { financial support to the public } \\
\text { education systems of states and } \\
\text { municipalities, and non-profit } \\
\text { community, faith-based or } \\
\text { philanthropic institutions. }\end{array}$ \\
\hline Participation social & Participation and social control. & $\begin{array}{l}\text { Participation of the population, } \\
\text { through representative } \\
\text { organizations. }\end{array}$ & Family participation. \\
\hline
\end{tabular}


policies. While in health the focus is on illness or disability, without conceptual deepening, in social assistance and education the approach of the person with disability evidences the discourse of the social model of the disability explicitly stated, respectively, by the definition presented and the intertextuality with the Convention on the Rights of Persons with Disabilities. ${ }^{8}$

This model has consolidated the concept of disability as a social disadvantage due to the restriction of social participation caused by environmental and attitudinal barriers to individuals with specific health conditions and body alterations. The understanding of disability was contrasted only as a biomedical concept, which relates it to diseases and injuries verified in a body's expertise, revealing its political dimension and highlighting the oppression and discrimination of the disabled person due to the culture of normality. The approach to the social model of disability was adopted by the Convention on the Rights of Persons with Disabilities, which cites participation as a parameter for the formulation of social public policies for this population. ${ }^{22}$ The adoption of an approach based on the consequences of chronic conditions on children's social participation, regardless of categories of diagnosis, such as that developed in the Classificação Internacional de Funcionalidade, Incapacidade e Saúde (CIF - International Classification of Functioning, Disability and Health), may favor the recognition of their needs and their families' and the proposition of actions to meet their specificities, aiming at their quality of life and social inclusion. ${ }^{23}$

With regard to the strategies proposed in the legislation, the PNAISC defined seven strategic axes to guide and qualify the actions and services of children's health in the country. The policy was built due to the need to strengthen the proposed axes to promote Integrality of child care, articulating health actions at all levels of care and in all SUS management spheres. ${ }^{14}$ Previously, actions were organized in a programmatic perspective, and there was no national policy on children's health promulgated aimed at the universalization of actions in the national territory. ${ }^{24}$

The intertextuality manifests with other norms and the actions presented in each strategic axis of the policy show that the proposition of actions destined to the children with chronic diseases or disability is still incipient and vague. The prominence of actions aimed at the qualification of attention to the newborn is verified. Considering that the PNAISC is organized from the Health Care Network, ${ }^{14}$ the intertextuality with Ordinance No. 793 of 2012, which establishes the Network of Care for Persons with Disabilities under the Sistema Único de Saúde (Unified Health System), ${ }^{25}$ would allow a greater definition of the actions and structure for children with chronic conditions, especially for those with disabilities; however, this Ordinance was not mentioned.

Law No. 12,435 of 2011 adds to the Organic Law of Social Assistance the objectives of social assistance and defense of rights,,$^{15}$ in accordance with the text of the National Social Assistance Policy, and intertextuality is verified with Resolution No. 145 of 2004, establishing this policy. ${ }^{26}$ Since the enactment of the Organic Law on Social Assistance in 1993, "habilitation and rehabilitation" of persons with disabilities, the "promotion of their integration into community life" and the "guarantee of one (1) minimum monthly benefit salary" to those who "prove that they do not have the means to provide for their own maintenance or to have it provided by their family". ${ }^{21}$

With regard to this means of income transfer, called Benefício de Prestação Continuada (BPC - Continuous Benefit), it is worth highlighting the changes in the definitions of family and disabled people in the 2011 legislation. The family configuration is broadened beyond the "mononuclear unit", but the condition of "living under the same roof" is maintained, not contemplating the extended family. To grant the benefit, the definition of disabled person has been revised as previously discussed and it has been specified that long-term impairments are "those that disable the person with a disability for independent living and work for at least two (2) years". ${ }^{15,21}$

The adoption of the CIF guidelines in the instruments for the evaluation of the disabled persons requesting BPC made it possible to incorporate the biopsychosocial perspective. ${ }^{23}$ However, considering the determination that social assistance will be provided to those who need it according to the Federal Constitution and the definition of disability of the Convention on the Rights of Persons with Disabilities, the organic law of 2011 restricts the scope of social protection by linking long-term impediments to a minimum of two years and by reaffirming the text of the 1993 law, according to which social assistance must provide social minimums to meet basic needs. Social minimums, understood as minimum conditions of life or guarantee of survival, being adopted as a parameter for the provision of social assistance, instead of guaranteeing adequate standards of living, disrespect the principles of equality and universality of the Federal Constitution, aiming at reducing the budget impact of BPC. While it is necessary to specify criteria for the implementation of policy distributive strategies, consideration should be given to compromising the normative potential of the Convention by considering it "as a victory in the field of recognition struggles, ignoring the linkage it imposes in terms of distribution". 27:265

The organization of social assistance services addresses the creation of programs aimed at the "integration of the disabled person", which should be articulated with the benefit of continued provision, and programs of protection, among others, to children and adolescents in situations of personal or social risk. Although these programs are provided for in the laws of 1993 and 2011, the guidelines for implementing them or the regulations that regulate them have not been presented. ${ }^{15,21}$

Regarding specialized educational services, Decree No. 7,611 of 2011 provides that it is conceived as the set of activities, accessibility and pedagogical resources provided in a complementary way to the training for students with disabilities and global development disorders in the multifunctional resource room. ${ }^{16}$ The current decree revokes Decree No. 6,571 of 2008 on specialized educational services. ${ }^{28}$ Among the changes, we can highlight the guideline of "special education provision preferably in the regular network of education" and the definition that "specialized educational service to students of the public regular 
school system may be offered by public education systems or by community, confessional or nonprofit philanthropic institutions, with exclusive role in special education.

The resumption of care in specialized institutions reiterates the tension with the proposal of school inclusion of children with disabilities, which is also evidenced in the intertextuality with articles 58 to 60 that deals with the special education of the Law of Guidelines and Bases of National Education. The legislation provides that educational services should be provided in "specialized schools or services, provided that, depending on the specific conditions of the students, it is not possible to integrate them into the regular classes of regular education". ${ }^{29}$ From the perspective of school inclusion, this approach may represent a setback. In 1994, the National Special Education Policy conditioned access to regular classes to those able to follow the programmed curricular activities at the pace of "normal" students, while retaining the education of students with disabilities exclusively as the responsibility of special education. Only from the 2000s, regulations were developed to encourage the access of students with disabilities to the classes of regular schools. In 2008, the National Policy on Special Education was developed in the perspective of Inclusive Education. ${ }^{30}$

The texts of the regulations were constructed based on several other texts and discourses. There are intertextual chains explaining the references for the elaboration of policies and demarking relevant conceptions regarding the rights of the children, the way of organizing services and the strategies for the provision of actions. The Federal Constitution of $1988,{ }^{2}$ the $E C A^{5}$ and the norms promulgating international conventions on rights, such as the Convention on the Rights of the Child ${ }^{7}$ and the Convention on the Rights of Persons with Disabilities8 are highlighted as the main texts in all legislation. ${ }^{8}$

The principles and guidelines addressed in the texts reveal a multiplicity of discourses in the construction of policies. All legislation includes the discourses of children and people with disabilities as subjects of rights and the responsibility of the state to guarantee social rights. It is also evidenced the discourse of co-responsibility of the family, explaining their participation and aiming to foster family coexistence. Both in health and in social assistance, the discourse of social determination is identified.

The representations of children and people with disabilities built on the vocabulary and discourses of the laws analyzed show significance associated with the ideology of human rights, based on ideas of justice and social inclusion through structural reforms, in conflict with the ideology of normalization, based on the integration of people with disabilities through specialized centers in the community. Both ideologies were built in Western society after the Second World War in struggle against the hegemonic ideology of segregation, which used to adopt institutionalization. During this period, there was a convergence of ideas and movements in defense of human rights, with the conventions of the United Nations being elaborated; oppressed social groups, such as women, who have articulated themselves in search for social justice; investigations provoked criticism regarding the conditions of institutionalization; and the state of modern wellbeing emerged with the idea of social rights. ${ }^{31}$

In Brazil, legislation in force until the 1990s provided that, if the family could not or would fail to protect the child, the State would take over role. Children were confined to religious charities that were concerned with poverty, or in philanthropic institutions of a scientific nature that sought to manage social problems, working with poor children, "mentally ill", "disabled", or "delinquent" aimed at ordering deviations from a normality model. Social movements and non-governmental organizations mobilized themselves to change this model and introduce the rights of children and adolescents in the 1988 Federal Constitution. . $^{32,33}$

The analysis allows us to recognize the political effect of transforming the discourse of the 1988 Federal Constitution, which incorporates the state's duty to guarantee social rights in the legislative scope developed from its promulgation. After the establishment of the ECA, especially since 2000 , the rights of children are now regulated in the texts of legislation. The definition of public policies to ensure the social rights of children, including those with chronic diseases or disabilities, is confirmed, but the strategies and actions defined for this group of children are still vague. The area of education is highlighted with the definition of actions aimed at children with disabilities.

Despite these advances in the texts of the laws of education and social assistance, there is a persistence of vocabulary and meanings that refer to the discourse of integration and to the ideology of normalization in the discourse of the child and the person with disabilities as subjects of rights, revealing an interdiscursive conflict. This ideology addresses the reduction of difference through strategies that do not require a radical transformation of existing services, that is, they are in disagreement with egalitarian actions of the ideology of human rights, as recognition of differences and solidarity, ${ }^{31}$ which require the adaptation of society to eliminate barriers to citizen participation.

In addition, it is pertinent to question how much this discursive change has produced changes in the reality that promotes effective access to the rights, considering the Brazilian political, economic, social and ideological context. The institutionalization of the social protection model proposed in the Federal Constitution of 1988 has been conflictive due to the clash between the predicted and the governmental projects after its promulgation, in addition to the conflicts inherent to the democracy under construction. In this context, the liberal orientations that defend a strong reduction of the presence of the State in the economy and in social policies have been taken up. ${ }^{1,33}$ Since then, there have been "progressive policy hybrids with important restrictions on coverage, financing and quality of care, with low impact on the construction of social citizenship". ${ }^{34: 723}$

In the international context, in spite of the guarantee of CCCs' rights in the normative scope, studies showed challenges for its effectiveness. A study conducted in the United States on 
the coverage and adequacy of health insurance for children with special health needs indicated a decrease in private coverage to $50.7 \%$, an increase in public coverage to $34.7 \%$ and a reduction in the number of children with no insurance to $3.5 \%$. The proportion of children with adequate coverage declined in terms of the private coverage to $59.6 \%$ and increased in public coverage to $70.7 \%$. The authors emphasized that both national and state policy efforts will be required to achieve the goal of all children with special health needs to have continuous and adequate health insurance coverage to meet their needs. ${ }^{35}$

The results of research conducted in seven European countries on school inclusion policies for children with disabilities due to cerebral palsy showed that $46 \%$ of the children were in special classes or schools, although the educational policy of those countries was favorable to inclusion in regular schools. Children with more severe disabilities were rarely included in regular schools and visually impaired children attended special schools in all countries. Significant differences were found between regions because of changes in national policies. ${ }^{36}$

Studies carried out in South Africa, ${ }^{37}$ Egypt $^{38}$ and China ${ }^{39}$ found that the majority of children with disabilities did not have access to health services, ${ }^{37-39}$ education ${ }^{37,38}$ and social assistance ${ }^{37,38}$ to meet their needs and guarantee their rights. The authors emphasized the State's urgency to prioritize the implementation of policies to guarantee the rights of children with disabilities, providing resources to expand the range of services and make them accessible. In addition, they addressed the importance of informing caregivers about the service network ${ }^{37,39}$ and educating the population about the rights of these children to take responsibility for their promotion and protection. ${ }^{38}$

Although the legal system directs the transformation of social relations in affirming children and people with disabilities as subjects of rights, there is still an ideological struggle in society with different representations of children with chronic conditions, showing discrimination and social exclusion of those who are different. Thus, in addition to the State, the family and society are essential in terms of the recognition of these children..$^{40}$ In order for legislation to be a tool for changing discursive practices and ideologies built on them, reversing the social invisibility of CCC, it is necessary to distribute and consume the text of these regulations by managers and professionals from health, education and care institutions, teachers, family members and representatives of these children.

Family participation was envisaged in education legislation and popular participation, as a social control practice, was envisaged in health and welfare legislation. This participation together with the political action of social movements and organizations in the fight for a more just and dignified society is important to build a conception and practice against the hegemony of human rights ${ }^{41}$ and for maintenance and investment in social policies by the State. ${ }^{42}$

In this way, the participation of the families of the $\mathrm{CCC}$, social movements and organizations in councils and other negotiating bodies can make effective and qualify the offer of actions foreseen in these policies, contemplating the differences in terms of subjectivity. This article may contribute to the dissemination of legislation guaranteeing rights to such children. In the study, the policies were analyzed until the formulation phase and the choice of solutions to the problems. It is recommended to carry out research to evaluate the phases of implementation and evaluation of policies in the states and municipalities.

\section{CONCLUSIONS AND IMPLICATIONS FOR PRACTICE}

In Brazilian public policies that guarantee social rights to CCC, these are represented mainly by children with chronic diseases or with disabilities. The disability approach is in line with the social model of disability in welfare and education legislation. The discourses reveal the child and the person with disabilities as subjects of rights and the responsibility of the State to guarantee social rights, with co-responsibility of the family. Discourses associated to the ideology of human rights in interdiscursive conflict with the ideology of normalization were evidenced. It is concluded that the strategies and actions defined for this group of children are still incipient and with signs of restricting financing, revealing ideological struggles.

Therefore, in order to guarantee the social rights of CCC through state institutions, it is necessary to specify actions to meet their needs through state institutions, considering the ideology of human rights, and invest resources for the universality of coverage and quality of care. In order for legislation to be a tool for changing the discursive practices and ideologies built on it, it is necessary to disseminate its information among social actors of management, attention, training and social control, including $\mathrm{CCC}$ and their families, with the aim of guiding their performance and their demand for social public policies.

\section{ACKNOWLEDGEMENT}

To the Conselho Nacional de Ciência e Tecnologia (CNPq), 480206/2013-9 and the Fundação de Amparo à Pesquisa de Minas Gerais (FAPEMIG), APQ-01889-13.

\section{REFERENCES}

1. Fleury S. Brazilian sanitary reform: dilemmas between the instituing and the institutionalized. Ciênc Saúde Coletiva [Internet]. 2009 May-Jun; [cited 2016 Dec 15]; 14(3):743-52. Available from: http://www.scielo.br/scielo. php?script=sci_arttext\&pid=S1413-81232009000300010\&Ing=en

2. Constituição da República Federativa do Brasil de 1988 (BR). Diário Oficial da União. [Internet], Brasília (DF). 1988 Oct 5[cited 2016 Dec 15]. Available from: https://www.planalto.gov.br/ccivil_03/constituicao/ constituicaocompilado.htm

3. Stein RE. The 1990s: a decade of change in understanding children with ongoing conditions. Arch Pediatr Adolesc Med [Internet].2011 Oct [cited 2016 Dec 15]; 165(10):880-3. Available from: http://jamanetwork. com/journals/jamapediatrics/fullarticle/1107600

4. Perez JRR, Passone EF. Social policies for children and adolescents in Brazil. Cad Pesqui [Internet]. 2010 May/Aug; [cited 2016 Dec 15]; 40(140):649-73. Available from: http://www.scielo.br/scielo.php?script=sci_ arttext\&pid=S0100-15742010000200017\&lng=en\&nrm=iso 
5. Lei $n^{\circ} 8.069$ de 13 de julho de 1990 (BR). Dispõe sobre o Estatuto da Criança e do Adolescente e dá outras providências. Diário Oficial da União [Internet], Brasília (DF). 1990 Jul 13 [cited 2016 Dec 15]. Available from: https://www.planalto.gov.br/ccivil_03/leis/L8069.htm

6. Lei $n^{\circ} 13.146$ de 6 de julho de 2015 (BR). Institui a Lei Brasileira de Inclusão da Pessoa com Deficiência (Estatuto da Pessoa com Deficiência). Diário Oficial da União [Internet], Brasília (DF). 2015 Jul 5 [cited 2016 Dec 15]. Available from: http://www.planalto.gov.br/ ccivil_03/_ato2015-2018/2015/Lei/L13146.htm

7. Decreto $\mathrm{n}^{\circ} 99.710$ de 21 de novembro de 1990 (BR). Promulga a Convenção sobre os Direitos da Criança. Diário Oficial da União [Internet], Brasília (DF). 1990 Nov 21 [cited 2016 Dec 15]. Available from: http://www.planalto.gov.br/ccivil_03/decreto/1990-1994/D99710. $\mathrm{htm}$

8. Decreto $\mathrm{n}^{\circ} 6.949$ de 25 de agosto de 2009 (BR). Promulga a Convenção Internacional sobre os Direitos das Pessoas com Deficiência e seu Protocolo Facultativo, assinados em Nova York, em 30 de março de 2007. Diário Oficial da União [Internet], Brasília (DF). 2009 Aug 25 [cited 2016 Dec 15]. Available from: http://www.planalto.gov.br/ ccivil_03/_Ato2007-2010/2009/Decreto/D6949.htm

9. Tavares TS, Sena RR, Duarte ED. Implications for nursing care concerning children discharged from a neonatal unit with chronic conditions. Rev Rene [Internet]. 2016 Sep/Oct; [cited 2016 Dec 15]; 17(5):659-67. Available from: http://www.periodicos.ufc.br/index.php/ rene/article/view/6197/4433

10. Nóbrega VM, Reichert APS, Viera CS, Collet N. Longitudinality and continuity of care for children and adolescents with chronic diseases. Esc Anna Nery [Internet]. 2015 Oct/Dec; [cited 2016 Dec 15]; 19(4):65663. Available from: http://www.scielo.br/scielo.php?script=sci arttext\&pid=S1414-81452015000400656\&lng=en\&nrm=iso

11. Batista Júnior JR, Sato DTB. Inclusive education in Brazil: discourse and literacy practices. Discurso Soc [Internet]. 2015; [cited 2016 Dec 15]; 9(1-2):201-21. Available from: http://www.dissoc.org/ediciones/ v09n01-2/DS9(1-2)Ribamar\&Borges.pdf

12. Santos WR. Deficiency and BPC: what changes in the lives of people assisted? Ciênc Saúde Coletiva [Internet]. 2011; [cited 2016 Dec 15]; 16(Suppl. 1):787-96. Available from: http://www.scielo.br/scielo. php?script=sci_arttext\&pid=S1413-81232011000700009\&lng=en\&n $\mathrm{rm}=\mathrm{iso}$

13. Santos BS. Pela mão de Alice: o social e o político na pós-modernidade. 14ª ed. São Paulo: Cortez; 2013. 542 p.

14. Portaria $n^{\circ} 1.130$ de 5 de agosto de 2015 (BR). Institui a Política Nacional de Atenção Integral à Saúde da Criança (PNAISC) no âmbito do Sistema Único de Saúde (SUS). Diário Oficial da União [Internet], Brasília (DF). 2015 Aug 5 [cited 2016 Dec 15]. Available from: http:// bvsms.saude.gov.br/bvs/saudelegis/gm/2015/prt1130_05_08_2015. $\mathrm{html}$

15. Lei $n^{\circ} 12.435$ de 6 de julho de 2011 (BR). Altera a Lei no 8.742, de 7 de Dezembro de 1993, que dispõe sobre a organização da Assistência Social. Diário Oficial da União [Internet], Brasília (DF). 2011 Jul 6 [cited 2016 Dec 15]. Available from: https://www.planalto.gov.br/ ccivil_03/_ato2011-2014/2011/lei/l12435.htm

16. Decreto $\mathrm{n}^{\circ} 7.611$ de 17 de novembro de 2011 (BR). Dispõe sobre a educação especial, o atendimento educacional especializado e dá outras providências. Diário Oficial da União [internet], Brasília (DF). 2011 Jul 6 [cited 2016 Dec 15]. Available from: http://www.planalto. gov.br/ccivil_03/_ato2011-2014/2011/decreto/d7611.htm

17. Fairclough N. Analysing discourse: Textual analysis for social research. New York: Routledge; 2003. 270p.

18. Boito Jr A, Berringer T. Brazil: social class, neo-developmentism and foreign policy in governments Lula and Dilma. Rev Sociol Polit [Internet]. 2013 Sep; [cited 2016 Dec 15]; 21(47):31-8. Available from: http://www.scielo.br/scielo.php?script=sci_arttext\&pid=S0104$44782013000300004 \&$ Ing=en\&nrm=iso
19. Ministério do Planejamento, Orçamento e Gestão, Instituto Brasileiro de Geografia e Estatística (IBGE). Censo Demográfico 2010: Características gerais da população, religião e pessoas com deficiência. Rio de Janeiro: Ministério do Planejamento, Orçamento e Gestão, IBGE; 2010.215 p.

20. Barros MBA, Francisco PMSB, Zanchetta LM, César CLG. Trends in social and demographic inequalities in the prevalence of chronic diseases in Brazil. PNAD: 2003-2008. Ciênc Saúde Coletiva [Internet]. 2011 Sep; [cited 2016 Dec 15]; 16(9):3755-68. Available from: http://www.scielo.br/scielo.php?script=sci_arttext\&pid=S1413$81232011001000012 \& \operatorname{lng}=e n \& n r m=i s o$

21. Lei no 8.742 de 7 de Dezembro de 1993 (BR). Dispõe sobre a organização da Assistência Social e dá outras providências. Diário Oficial da União [Internet], Brasília (DF). 1993 Dec 7 [cited 2016 Dec 15]. Available from: http://www.planalto.gov.br/ccivil_03/Leis/L8742. htm

22. Santos W. Disability as a restriction on social participation: challenges in evaluation since the Brazilian Inclusion of People with Disabilities Act. Ciênc Saúde Coletiva [Internet]. 2016 Oct; [cited 2016 Dec 15]; 21(10):3007-15. Available from: http://www.scielo.br/scielo. php?script=sci_arttext\&pid=S1413-81232016001003007\&lng=en\&n $\mathrm{rm}=\mathrm{iso}$

23. Duarte ED, Silva KL, Tavares TS, Nishimoto CLJ, Silva PM, Sena RR. Care of children with a chronic condition in primary care: challenges to the healthcare model. Texto Contexto Enferm [Internet] 2015 Oct/Dec; [cited 2016 Dec 15]; 24(4):1009-17. Available from: http://www.scielo.br/scielo.php?script=sci_arttext\&pid=S010407072015000401009\&lng=en

24. Pinto CAG, Paraguay NLBB, Ferrer AL, Emerich BF, Gigante RL, Oliveira MM, et al. Introduction to the evaluative research of the formulation and implementation process of the National Policy for Comprehensive Child Health Care (PNAISC). Divulg Saúde Debate. 2016;55:18-30.

25. Portaria $n^{\circ} 793$ de 24 de abril de 2012 (BR). Institui a Rede de Cuidados à Pessoa com Deficiência no âmbito do Sistema Único de Saúde. Diário Oficial da União [internet], Brasília (DF). 2012 Apr 24 [cited 2016 Dec 15]. Available from: http://bvsms.saude.gov.br/bvs/saudelegis/ gm/2012/prt0793_24_04_2012.html

26. Ministério do Desenvolvimento Social e Combate à Fome, Secretaria Nacional de Assistência Social (BR). Política Nacional de Assistência Social PNAS/2004. Brasília: Ministério do Desenvolvimento Social e Combate à Fome; 2009. 175 p.

27. Silva JLP, Diniz D. Social minimum and equality: deficiency and LOAS assistance benefits. Rev Katálysis [Internet]. 2012 Jul/Dec; [cited 2016 Dec 15]; 15(2):262-9. Available from: http://www.scielo.br/scielo. php?script=sci_arttext\&pid=S1414-49802012000200012\&lng=en\&nr $m=$ iso

28. Decreto no 6.571 de 17 de setembro de 2008 (BR). Dispõe sobre o atendimento educacional especializado, regulamenta o parágrafo único do art. 60 da Lei no 9.394, de 20 de Dezembro de 1996, e acrescenta dispositivo ao Decreto oㅜ 6.253, de 13 de novembro de 2007. Diário Oficial da União [Internet], Brasília (DF). 2008 Sep 17 [cited 2016 Dec 15]. Available from: http://www.planalto.gov.br/ccivil_03/_Ato20072010/2008/Decreto/D6571impressao.htm

29. Lei oํ 9.394 de 20 de Dezembro de 1996 (BR). Estabelece as diretrizes e bases da educação nacional. Diário Oficial da União [Internet], Brasília (DF). 1996 Dec 20 [cited 2016 Dec 15]. Available from: https:// www.planalto.gov.br/ccivil_03/Leis/L9394.htm

30. Kassar MCM. Special education on the perspective of inclusive education: implementation challenges of a national policy. Educ Rev [Internet]. 2011 Jul/Sep; [cited 2016 Dec 15]; 41:61-79. Available from: http://www.scielo.br/scielo.php?script=sci_arttext\&pid=S010440602011000300005\&lng=en\&nrm=iso 
31. Mcdonnell P. Disability, deafness and ideology in the late twentieth and early twenty-first centuries. Educ Real [Internet]. $2016 \mathrm{Jul} / \mathrm{Sep}$; [cited 2016 Dec 15]; 41(3):777-88. Available from: http://www.scielo.br/scielo. php?script=sci_arttext\&pid=S2175-62362016000300777\&Ing=en\&nrm =iso

32. Arantes EMM. Rostos de crianças no Brasil. In: Rizzini I, Pilotti F, orgs. A arte de governar crianças: a história das políticas sociais, da legislação e da assistência à infância no Brasil. São Paulo: Cortez; 2011. p. 153-202.

33. Araújo JP, Silva RMM, Collet N, Neves ET, Tos BRGO, Viera CS. History of the child's health: conquers, policies and perspectives. Rev Bras Enferm [Internet]. 2014 Nov/Dec; [cited 2016 Dec 15]; 67(6):1000-7. Available from: http://www.scielo.br/scielo.php?script=sci_arttext\&pid=S0034$71672014000601000 \&$ Ing $=$ en

34. Lobato LVC. Dilemmas of the institutionalization of social policies in twenty years of the Brazilian Constitution of 1988. Ciênc Saúde Coletiva [Internet]. 2009 May/Jun; [cited 2016 Dec 15]; 14(3):721-30. Available from: http://www.scielo.br/scielo.php?script=sci arttext\&pid=S1413$81232009000300008 \& \operatorname{lng}=$ en

35. Ghandour RM, Comeau M, Tobias C, Dworetzky B, Hamershock R, Honberg L, et al. Assuring Adequate Health Insurance for Children With Special Health Care Needs: Progress From 2001 to 2009-2010. Acad Pediatr [Internet]. 2015 Jul/Aug; [cited 2017 Apr 24]; 15(4):45160. Available from: http://www.academicpedsjnl.net/article/S18762859(15)00044-3/abstract

36. Sentenac M, Ehlinger V, Michelsen SI, Marcelli M, Dickinson HO, Arnaud C. Determinants of inclusive education of 8-12 year-old children with cerebral palsy in 9 European regions. Rev Dev Disabil [Internet]. 2013
Jan; [cited 2017 Apr 24]; 34(1):588-95. Available from: http://www. sciencedirect.com/science/article/pii/S0891422212002521

37. Saloojee G, Phohole M, Saloojee H, IJsselmuiden C. Unmet health, welfare and educational needs of disabled children in an impoverished South African peri-urban township. Child Care Health Dev [Internet]. 2007 May; [cited 2017 Apr 24]; 33(3):230-5. Available from: http:/ onlinelibrary.wiley.com/doi/10.1111/j.1365-2214.2006.00645.x/abstract

38. Gobrial E. Mind the gap: the human rights of children with intellectua disabilities in Egypt. J Intellect Disabil Res [Internet]. 2012 Nov; [cited 2017 Apr 24]; 56(11):1058-64. Available from: http://onlinelibrary.wiley. com/doi/10.1111/j.1365-2788.2012.01650.x/abstract

39. Fisher KR, Shang $X$. Access to health and therapy services for families of children with disabilities in China. Disabil Rehabil [Internet]. 2013 Apr; [cited 2017 Apr 24]; 35(25):2157-63. Available from: http://www. tandfonline.com/doi/abs/10.3109/09638288.2013.770566

40. Honneth $A$. The I in we: recognition as a driving force of group formation Sociologias [Internet]. 2013 May/Aug; [cited 2016 Dec 15]; 15(33):5680. Available from: http://www.scielo.br/scielo.php?script=sci arttext\&pid=S1517-45222013000200003\&lng=en\&nrm=iso

41. Santos BS, Chaui M. Direitos humanos, democracia e desenvolvimento. São Paulo: Cortez; 2013. 133 p.

42. Pessoto UC, Ribeiro EAW, Guimarães RB. The role of the state in public health policies: an overview of the debate on the concept of State and the Brazilian case. Saúde Soc [Internet]. 2015 Jan/Mar; [cited 2016 Dec 15]; 24(1):9-22. Available from: http://www.scielo.br/scielo. php?script=sci_arttext\&pid=S0104-12902015000100009\&lng=en 